\title{
Corporate Governance and Corporate Social Responsibility Synergies and Interrelationships
}

\author{
Dima Jamali*, Asem M. Safieddine and Myriam Rabbath
}

\begin{abstract}
Manuscript Type: Empirical

Research Questions/Issue: This paper seeks to explore the interrelationships between corporate governance (CG) and corporate social responsibility (CSR): first, theoretically, by reviewing the literature and surveying various postulations on offer; second, empirically, by investigating the conception and interpretation of this relationship in the context of a sample of firms operating in Lebanon. Accordingly, the paper seeks to highlight the increasing cross-connects or interfaces between CG and CSR, capitalizing on fresh insights from a developing country perspective.

Research Findings/Results: A qualitative interpretive research methodology was adopted, drawing on in-depth interviews with the top managers of eight corporations operating in Lebanon, with the findings suggesting that the majority of managers conceive of CG as a necessary pillar for sustainable CSR. These findings are significant and interesting, implying that recent preoccupation with CG in developing countries is starting to be counterbalanced by some interest/attention to CSR, with growing appreciation of their interdependencies and the need to move beyond CG conformance toward voluntary CSR performance.

Theoretical Implications: This study makes two important contributions. First, it suggests that there is a salient two-way relationship and increasing overlap between CG and CSR. While much previous literature has researched CG and CSR independently, this paper makes the case for considering them jointly and systematically. Second, the paper outlines a number of theoretical propositions that can serve as the basis for future research on the topic, particularly in developing countries, given that the data and theoretical propositions are both derived from and tailored to developing country contexts.

Practical Implications: This study can potentially alert managers to the increasing overlap between the CG and CSR agendas and the need to exert diligent systematic efforts on both fronts. CG and CSR share more in common than previously assumed, and this needs to be accounted for by practitioners. The research can also alert policy makers in developing countries to the need to increase the vigilance and capacity of the regulatory and judicial systems in the context of CG reform and to increase institutional pressures, particularly of the coercive and normative variety to enhance CSR adoption.
\end{abstract}

Keywords: Institutional Theory, Corporate Social Responsibility, Business Outcomes, National Outcomes

\section{INTRODUCTION}

C orporations have traditionally been conceived as selfcentered, profit-maximizing entities constituting the central tenets of capitalism and free market philosophies $(\mathrm{Hg}, 2007)$. Until recently, the connections between capitalism, economic growth, and self-interested corporation have largely gone unquestioned in policy circles $(\mathrm{Hg}, 2007)$. However, recent and monumental corporate scandals and

*Address for correspondence: University of Southampton - School of Management, Highfield Southampton SO17 1BJ, UK. Tel: +44 (0) 238059 8961; Fax: +44 (0) 238059 3844; E-mail: D.Jamali@soton.ac.uk failures have redirected attention to issues of good governance, ethics, trust, and accountability, heightening the debate on topics of corporate governance (CG) and the ethics of economic conduct (Marsiglia and Falautano, 2005). Accordingly, at no time in history have the role and power of the corporation been accorded more popular attention and concern, with the pure profit maximization axiom increasingly called into question.

While shareholder value maximization is still a major goal for corporations worldwide, the rise in social activism and the emergence of new expectations have indeed caused other aspects of corporate performance to be examined alongside financial results. As firms grow in size and influence, they are 
no longer expected to be mere contributors to the global economy, but rather to reconcile and skillfully balance multiple bottom lines and manage the interests of multiple stakeholders (Jamali, 2006). There is some recent evidence to suggest that organizations are generally more inclined today to broaden the basis of their performance evaluation from a short-term financial focus to include long-term social, environmental, and economic impacts and value added (Hardjono and van Marrewijk, 2001).

This is where the concepts of CG and corporate social responsibility (CSR) enter the picture. Under the umbrella of CG, companies are encouraged to promote ethics, fairness, transparency, and accountability in all their dealings. They are expected to continue generating profits while maintaining the highest standards of governance internally. A firm's decisions should also be aligned with the interests of different players within and outside the company (Freeman, 1984). Hence, businesses have to also keep their activities attuned to society's ethical, legal, and communal aspirations. This falls in the realm of CSR, which has attracted increasing attention in recent years in relation to how companies approach their interactions with their various stakeholders - from providing quality products and services, to undertaking charitable activities.

Much of the previous literature has researched and discussed CG and CSR independently, as being unrelated accountability models, whose guidelines, reporting standards, and oversight mechanisms have evolved separately (Bhimani and Soonawalla, 2005). However, we feel that CG and CSR are strongly and intricately connected, and that previous literature has fallen short in capturing the nature and essence of this relationship. As Bhimani and Soonawalla (2005) put it, CG and CSR are two sides of the same coin. This paper will explore this relationship in depth; first, theoretically, by reviewing the literature and highlighting how this CG-CSR relationship has been posited. Through a qualitative study in the Lebanese context, this paper will also investigate managerial interpretation and practical application of CG and CSR, their understanding of the nature of this relationship, as well as their efforts at pragmatic integration of each of these two paradigms in their daily operations.

\section{LITERATURE REVIEW}

\section{Corporate Governance Literature}

This paper will focus on an important - and in no way simplistic - definition of CG as "the system by which companies are directed and controlled" (Cadbury, 2000: 8). The control aspect of CG encompasses the notions of compliance, accountability, and transparency (MacMillan, Money, Downing and Hillenbrad, 2004), and how managers exert their functions through compliance with the existing laws and regulations and codes of conduct (Cadbury, 2000). The importance of CG lies in its quest at crafting/continuously refining the laws, regulations, and contracts that govern companies' operations, and ensuring that shareholder rights are safeguarded, stakeholder and manager interests are reconciled, and that a transparent environment is maintained wherein each party is able to assume its responsibilities and contribute to the corporation's growth and value creation
(Page, 2005). Governance thus sets the tone for the organization, defining how power is exerted and how decisions are reached.

A narrow view of CG portrays it as an enforced system of laws and of financial accounting, where socioenvironmental considerations are accorded a low priority (Saravanamuthu, 2004). There is, however, a broader CG conception, emphasizing every business' responsibilities toward the different stakeholders that provide it with the necessary resources for its survival, competitiveness, and success (MacMillan et al., 2004). As such, managers are primarily accountable toward stockholders whose wealth and fortunes are at stake. But they are also responsible toward employees, suppliers, customers, and communities whose investments in the company are equally significant in other important respects. Thus, within this broader conception, the interests of all stakeholders are accorded due regard and consideration and posited as constraints on managerial action and shareholder rights (Kendall, 1999; Page, 2005).

Other focal elements or ingredients of good governance include corporate leadership and strategy setting. These aspects involve defining roles and responsibilities, orienting management toward a long-term vision of corporate performance, setting proper resource allocation plans, contributing know-how, expertise, and external information, performing various watchdog functions, and leading the firm's stakeholders in the desired direction (MacMillan et al., 2004; Cadbury, 2000; Page, 2005). The leadership and control aspects of CG are thus not mutually exclusive; rather, they go hand in hand, and they both define the extent of power accorded to various stakeholders, including executives, managers, employees, and, to a lesser extent, external constituencies and actors (MacMillan et al., 2004). Leaders in this respect should exercise their flair in taking their companies forward, while according due regard to their responsibilities to shareholders and stakeholders (Mallin, 2005).

Corporate Governance is also intimately concerned with honesty and transparency, which are increasingly expected of the public both in corporate dealings and disclosure (Page, 2005). Investor confidence and market efficiency depend on the disclosure of accurate information about corporate performance. To be of value in global capital markets, disclosed information should be clear, consistent, and comparable (OECD, 1999). Moreover, transparency and disclosure of information between managers and employees are essential to earn employee trust and commitment. These factors ensure an accurate and timely reporting of activities, thus providing the necessary underpinning that would facilitate the application of sound governance mechanisms (Cadbury, 2000).

While the above focuses primarily on internal governance mechanisms and principles, a holistic view of CG needs to also account of external governance mechanisms, including the takeover market and the legal system (Denis and McConnell, 2003). Admitting that the legal system is a universally important CG mechanism, providing for the protection of investor rights and enforcement of rules (La Porta, Lopez de Silanes, Shleifer and Vishny, 1998), the market for corporate control becomes salient when there is enough incentive for outside parties to seek control of the firm or, in other words, when internal control mechanisms fail to a large degree (Denis and McConnell, 2003). Given the 
TABLE 1

Basic Principles of Corporate Governance

OECD principles

Protection of shareholders' rights

Equitable treatment of shareholders

Protection of stakeholders' rights

Accurate disclosure of information

Diligent exercise of board

responsibilities
Description

Entails the protection of shareholders and maintaining investor confidence at all times in way of ensuring the continuous inflow of needed capital.

Entails the equitable treatment of all equity investors, including minority shareholders.

Entails the skillful consideration and balancing of the interests of all stakeholders, including employees, customers, partners, and the local community.

Entails the accurate and timely disclosure of clear, consistent, and comparable information in good times and bad times.

Board elections should be totally free from political interference and board members should exercise their responsibilities diligently and independently.

OECD, Organization for Economic Cooperation and Development (1999).

dynamic interrelationships among various CG mechanisms, external aspects invariably deserve consideration to provide a contextualized understanding of firm-specific internal CG dimensions.

In summary, CG thus generally revolves around a set of universal attributes, including ensuring accountability to shareholders and other stakeholders (Keasy and Wright, 1997), creating mechanisms to control managerial behavior (Tricker, 1994), ensuring that companies are run according to the laws and answerable to all stakeholders (Dunlop, 1998), ensuring that reporting systems are structured in such a way that good governance is facilitated (Kendall, 1999), crafting an effective leadership/strategic management process that incorporates stakeholder value as well as shareholder value (Tricker, 1994; Kendall, 1999), and enhancing accountability and corporate performance (Keasy and Wright, 1997). Leadership, direction, control, transparency, and accountability attributes thus lie at the heart of sound and effective CG (Huse, 2005; Van den Berghe and Louche, 2005).

A variation of these core attributes is articulated in turn in the OECD Principles (1999), listed and described in Table 1. These principles, originally adopted by the 30 member countries of the OECD in 1999, have become a reference tool for countries all over the world (Jesover and Kirkpatrick, 2005), providing an international benchmark for $C G$, and specific guidance for policy makers, regulators, and market participants in improving the legal, institutional, and regulatory framework that underpins CG. These principles have exhibited a good level of adaptability in varying legal, economic, and cultural contexts, and they have served as the basis for various reform initiatives by governments and the private sector in different countries (Jesover and Kirkpatrick, 2005).

\section{Corporate Social Responsibility Literature}

CSR on the other hand is a concept that has attracted worldwide attention and acquired a new resonance in the global economy (Jamali, 2006). Heightened interest in CSR in recent years has stemmed from the advent of globalization and international trade, which have reflected in increased business complexity and new demands for enhanced transparency and corporate citizenship. Moreover, while governments have traditionally assumed sole responsibility for the improvement of the living conditions of the population, society's needs have exceeded the capabilities of governments to fulfill them (Jamali, 2006). In this context, the spotlight is turning to focus on the role of business in society, and companies are seeking to differentiate themselves through engagement in what is referred to as CSR. The World Business Council for Sustainable Development (WBCSD) defines CSR as the commitment of business to contribute to sustainable economic development, working with employees, their families and the local communities (WBCSD, 2001). More generally, CSR is a set of policies, practices, and programs that are integrated throughout business operations and decision-making processes, and intended to ensure the company maximizes the positive impacts of its operations on society (Business for Social Responsibility, 2003).

The most common conceptualizations of CSR are those of Carroll (1979) and Lantos (2001). Carroll (1979; 1991) differentiated between four types of CSR, namely, economic (jobs, wages, services), legal (legal compliance and playing by the rules of the game), ethical (being moral and doing what is just, right, and fair) and discretionary (optional philanthropic contributions), while Lantos (2001) collapsed these categories into three: ethical, altruistic, and strategic. According to Lantos (2001), ethical CSR is morally mandatory and goes beyond fulfilling a firm's economic and legal obligations, to its responsibility to avoid harm or social injuries, even in cases where the business does not directly benefit. Altruistic CSR, according to Lantos (2001), is humanitarian/ philanthropic CSR, which involves genuine optional caring, irrespective of whether the firm will reap financial benefits or not. Examples include efforts to alleviate public problems (e.g., poverty, illiteracy) in an attempt to enhance society's welfare and improve the quality of life. Strategic CSR on the other hand is strategic philanthropy aimed at achieving strategic business goals while also promoting societal welfare 
TABLE 2

Preliminary Links between Corporate Governance (CG) and Corporate Social Responsibility (CSR)

Corporate governance

CSR

Broader CG conception: Entails due regard to all stakeholders and ensuring that firms are answerable to all their key stakeholders (Dunlop, 1998; Kendall, 1999)

Narrow CG conception: Ensuring accountability, compliance, and transparency (Keasy and Wright, 1997; MacMillan et al., 2004)

Stakeholder approach to CSR: Corporations are the crux of a complex web of stakeholder relationships and have an obligation or responsibility to these different stakeholders (Freeman, 1984)

Internal dimension of CSR: Corporations should accord due diligence to their responsibility to internal stakeholders addressing issues relating to skills and education, workplace safety, working conditions, human rights, equity/equal opportunity, and labor rights (Grosser and Moon, 2005; Jones et al., 2005)

(Jamali, 2007). The company strives to identify activities and deeds that are believed to be good for business as well as for society (Quester and Thompson, 2001).

Many scholars also conceive of CSR as encompassing two dimensions: internal and external. On the internal level, companies revise their in-house priorities and accord due diligence to their responsibility to internal stakeholders, addressing issues relating to skills and education, workplace safety, working conditions, human rights, equity considerations, equal opportunity, health and safety, and labor rights (Jones, Comfort and Hillier, 2005). With respect to the external dimension of CSR - which admittedly receives more attention in the literature (Deakin and Hobbs, 2007) priority shifts to the need for corporations to assume their duties as citizens, and accord due diligence to their external - economic and social - stakeholders and the natural environment (Munilla and Miles, 2005). The environmental component addresses primarily the impacts of processes, products, and service on the environment, biodiversity, and human health, while the social bottom line incorporates community issues, social justice, public problems, and public controversies. Addressing these two CSR dimensions often implies difficult adjustments and willingness to consider multiple bottom lines (Elkington, 2006). It also often requires good communication of CSR objectives and actions (Hancock, 2005), new standards, control and performance metrics (Lantos, 2001), and the successful integration of CSR into the culture of the organization (Jamali, 2006).

\section{Links between CG and CSR}

In light of the overview presented above, there is a discernable overlap between CG and CSR. More specifically, when considering the broader conception of $C G$, it is clear that good governance entails responsibility and due regard to the wishes of all key stakeholders (Kendall, 1999) and ensuring companies are answerable to all stakeholders (Dunlop, 1998). There is thus a clear overlap between this conception of CG and the stakeholder conception of CSR that considers business as responsible vis-à-vis a complex web of interrelated stakeholders that sustain and add value to the firm
(Freeman, 1984; Post, Preston and Sachs, 2002; Jamali, 2008). Conversely, various CSR scholars emphasize the need to uphold the highest standards of governance internally, particularly in discussions of the internal dimension of CSR (Perrini, Pogutz and Tencati, 2006; Rosam and Peddle, 2004; Grosser and Moon, 2005). These preliminary links are highlighted in Table 2.

Other links can also be detected. Both CG and CSR call on companies to assume their fiduciary and moral responsibilities toward stakeholders. This act of accountability is crucial for a business to gain and retain the trust of its financial investors and other stakeholders (Page, 2005). Both concepts thus draw vigor from the same sources, namely transparency, accountability, and honesty (Van den Berghe and Louche, 2005). Marsiglia and Falautano (2005) similarly suggest that good CG and CSR initiatives are gradually advancing from a philanthropic variant of corporate capitalism to authentic strategies intended to regain the trust of clients and society at large. While CG implies "being held accountable for," CSR means "taking account of" and both mechanisms are increasingly used by firms to regulate their operations (Beltratti, 2005; Marsiglia and Falautano, 2005). Windsor and Preston (1988) argue that, within the framework of legitimacy theory, CG and CSR are intricately related notions defining the interaction between an organization and its internal and external sociopolitical environment, with both increasingly considered as complementary fundamental prerequisites for sustainable growth within a globalizing business environment (Van den Berghe and Louche, 2005).

Both disciplines are also perceived to confer important long-lasting benefits and to ensure the endurance of the business. With respect to CG, it is observed that good governance mechanisms reconcile the interests of owners, managers, and all those dependent on the corporation, allowing corporations to secure long-term capital, retain the confidence of financiers, and to use the obtained capital proficiently. Gompers, Ishii and Metrick (2003), for example, find evidence that CG is significantly correlated with both stock returns and firm value. Ho (2005) reports evidence that good CG generally enhances firm competitiveness and results in 
FIGURE 1

Four Key Pillars of Corporate Social Responsibility (CSR) (Adapted from Hancock, 2005)

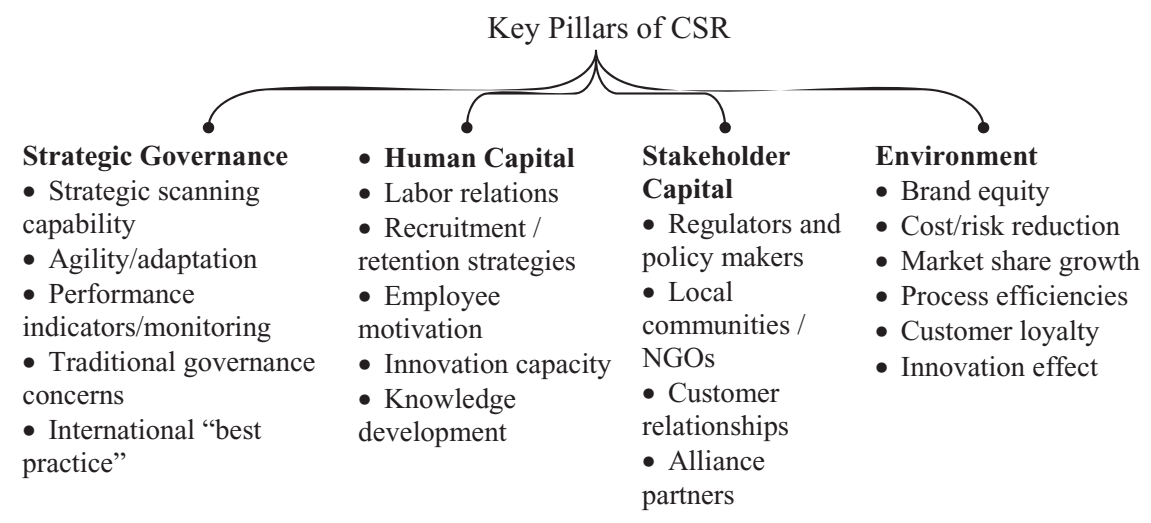

superior financial performance. CSR in turn increases the trustworthiness of a firm and strengthens relationships with core stakeholders (Aguilera, Rupp and Ganapathi, 2007), which may lead to decreased transaction costs and increased attractiveness in the eyes of investors (Hancock, 2005). While the business case for CSR remains controversial (Margolis and Walsh, 2003), a bulk of accumulating evidence suggests that CSR can result in lower environmental costs, enhanced innovation capability, improved recruitment/retention rates, increased employee satisfaction, and positive perceptions of the firm (Hancock, 2005; Aguilera et al., 2007; Barnett, 2007). Admittedly, short-term costs may be incurred when designing good CG and CSR initiatives, but there are also several indicators pointing to positive win-win outcomes for businesses that are seriously committed to both (Marsiglia and Falautano, 2005).

\section{Three Relational Models Examined}

While we have witnessed significant advances in research relating to each of these respective paradigms, and few recent formulations hinting to their cross-connections, some lingering questions persist, pertaining to their interrelationships, namely, are CG and CSR independent or interdependent functions? Are they mutually exclusive or mutually coexistent and increasingly convergent? A potential convergence is alluded to in a recent paper by Elkington (2006), where there is a mention of a progressive overlap between the CG agenda and the CSR and sustainable development agendas. Elkington (2006: 522) claims that "it is timely to review the increasingly complex cross-connects between the rapidly mutating governance agenda and the burgeoning world of CSR, social entrepreneurship and sustainable development." In heeding this call, we present here a review of several models which have posited a relationship between CG and CSR, namely: (1) CG as a pillar for CSR, (2) CSR as an attribute of CG, and (3) CG and CSR as coexisting components of the same continuum.

Model \# 1: CG as a Pillar of CSR. This depiction of CG as a pillar of CSR requires an effective CG system to be in place as a foundation for solid and integrated CSR activities. This is clearly illustrated in the postulation of Hancock (2005) who delineates four pillars for CSR, with strategic governance (entailing traditional CG concerns coupled with strategic management capability) highlighted as one of these core pillars. Hence, as illustrated in Figure 1, Hancock (2005) depicts CG as one of the main pillars of CSR along with human capital, stakeholder capital, and the environment (Figure 1).

Hancock (2005) argues that investor and senior management attention should be focused on these four core pillars, strategic governance, human capital, stakeholder capital, and the environment, which together help account for about 80 per cent of a company's true value and future valuecreating capacity. In other words, consistent with a resourcebased perspective (Barney, 2007; Wright, Dunford and Snell, 2007), the model argues that value creation, even in relation to CSR, is contingent on leveraging human, stakeholder, and environmental capital through (or coupled with) good strategic governance. CG is thus considered according to this model as one of CSR's basic building blocks. This conception is consistent with Elkington's (2006) who views CSR as the responsibility of corporate boards, and good CG as a foundational requirement or pillar for sustainable CSR.

Model \# 2: CSR as a Dimension of CG. Another model encountered in the literature is the one presented by Ho (2005), who considers CSR as an attribute or dimension of $C G$, thus widening the scope of $C G$, and incorporating nonfinancial risks into the risk mitigation dimension of CG activities. As illustrated in Figure 2, this conception of CG includes conventional dimensions or attributes (e.g., board structure, strategic leadership, stewardship, social responsibilities, and capital structure and market relations), as well as CSR. This is consistent with the writings of other authors (e.g., Kendall, 1999; OECD, 1999), who also consider CSR as an integral part of CG.

Ho (2005) proposes through this framework to gauge CG more holistically by considering a range of relevant attributes, including CSR. Her work builds in this respect on the work of Kendall (1999) who considers that good CG also entails ensuring that companies are run in a socially responsible way and that there should be a clearly ethical basis to 


\section{FIGURE 2}

\section{Corporate Social Responsibility Embedded in Corporate Governance (Adapted from Ho, 2005)}

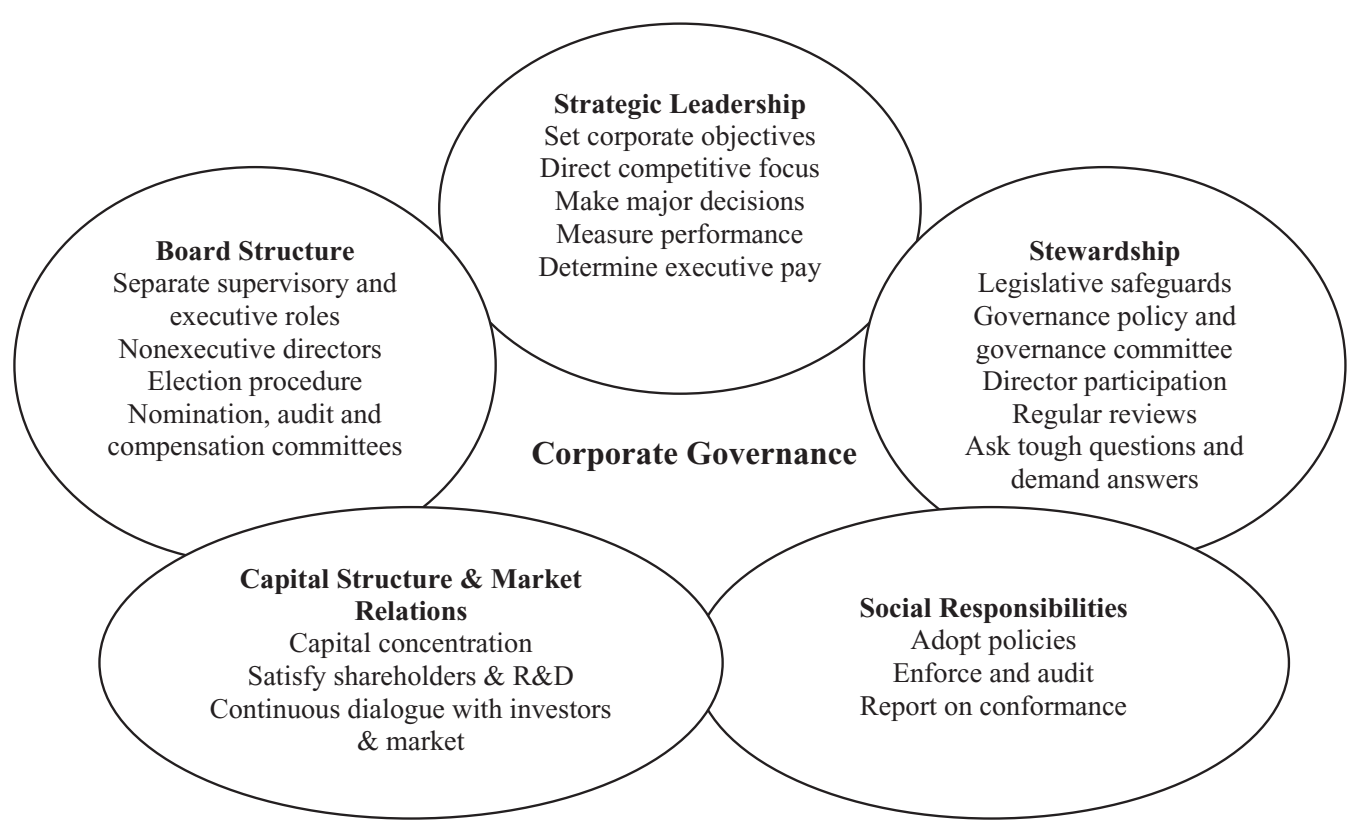

FIGURE 3

The Corporate Responsibilities Continuum (Bhimani and Soonawalla, 2005)

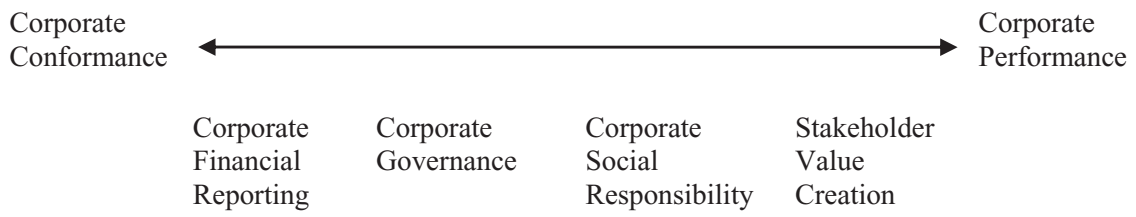

the business complying with the accepted norms of the society in which it is operating. In other words, according to this model, being responsible externally to the society at large and internally to employees should be embedded in CG formulations and structures. Ho's study (2005) provides evidence that higher commitments to CSR are strongly and positively related to the qualifications and terms of directors, boards that exercise strong stewardship and strategic leadership roles, and the management of capital market pressures, and that these various attributes combined constitute the hallmarks of good CG.

Model \# 3: CG and CSR as Part of a Continuum. Bhimani and Soonawalla (2005) portray CG and CSR as complementary constituents of the same corporate accountability continuum. They consider that poor CG and misleading financial statements are one side of the corporate coin - the other side being poor CSR (Bhimani and Soonawalla, 2005). Their corporate responsibilities continuum (Figure 3) is intended as an integrative framework, designed to reconcile conformance and performance reporting issues that should be articulated in a comprehensively integrated manner rather than disparately (Bhimani and Soonawalla, 2005). The continuum reflects varying degrees of compliance with laws and legally enforceable standards, with stress placed on corporate conformance on the left end of the continuum and attention shifting to corporate performance on the right end, where codes/standards are extremely difficult to apply, and oversight mechanisms are much less evident.

Implied in this model is the idea that CG has been the predominant focus of attention in research and practice, but this is starting to be counterbalanced by some interest in CSR and CSR reporting, which, while still not mandatory, is portrayed as increasingly desired (Bhimani and Soonawalla, 2005). The model presented here is also a good reminder of the nuances increasingly noted in the literature (e.g., Marsiglia and Falautano, 2005; Clarke, 2007) between legally binding requirements increasingly embodied in governance mechanisms requiring compliance and conformance, and self-regulatory stakeholder and CSR initiatives, which are evidence of voluntary corporate social performance. It is evident that even today, CG and compliance with continuously evolving legal requirements continue to draw more attention than voluntary CSR performance. Nevertheless, the continuum serves the purpose of delineating the basic building blocks of corporate accountability, with CG and 
compliance on the left-hand side constituting the basic cornerstone and the remaining items being gradually integrated in an attempt to strengthen overall accountability on a global basis.

We revisit those three models in the empirical section through a qualitative study in the Lebanese context, exploring managerial conceptions and practical application of CG and CSR, and their understanding of the nature of their interrelationships. The Lebanese context provides a fertile ground for an exploration of CG and CSR dynamics and their interrelationships, given that CG and CSR issues have attracted increasing attention in the postwar environment (Saidi, 2004). The Lebanese context could also provide interesting insights into the interplay of political economy constraints and CG/CSR applications, with potential relevance to other developing countries. We thus turn in the next section to provide a brief relevant contextual background about Lebanon followed by the presentation of the research methodology and empirical findings of the paper.

\section{BACKGROUND INFORMATION ABOUT LEBANON}

Lebanon is a small country located along the eastern shore of the Mediterranean sea bounded on the north and east by Syria and on the south by Israel, with a total area of 10,452 square kilometers and a population of around four million inhabitants. Lebanon qualifies as a parliamentary republic with a centralized, multireligious, and multiparty government. Its quasi-democratic political system is based on power sharing between the country's confessional groups. The grouping of people by religion plays a critical role in Lebanon's political and social life and has given rise to Lebanon's most persistent and bitter conflicts.

Since its independence from French rule in 1943, Lebanon has been characterized by large public freedoms, which have given it a distinctive position that made it a haven in the region, a place where different ideas, currents, and trends can thrive and interact. Peaceful multicultural coexistence, however, collapsed into violent warfare in the years 1975-1989. The conclusion of the Taef Accord of 1989 led to the reinstatement of security. However, the war, which Lebanon endured, interrupted the normal course of development, leading to an overall deterioration in political, economic, and social conditions.

Lebanon is now in the phase of reconstitution of its political, economic, and social structures and institutions. The first phase of reconstruction and development, namely the rehabilitation of the physical infrastructure, has been completed and has reestablished normal operations of public services. Daunting challenges, however, lie ahead particularly in terms of economic recovery. Postwar governments have pursued monetary stabilization policies aimed at curbing inflation rates and restoring confidence in the national currency. However, recent governments have had to go further in their stabilization policy to finance the growing budget deficit.

The main economic challenge confronted by successive governments in recent years has indeed been large recurring budget deficits, averaging more than 18 per cent of esti- mated GDP over 1997-2006. Efforts to restore fiscal balance have generally been undermined by the high costs and expenditures allocated to sustaining the postwar reconstruction program. Fiscal issues have therefore tended to dominate policy making in the postwar years, limiting the government's scope to adopt more growth-oriented measures, and accentuating the need for greater reliance on the private sector to promote growth, generate employment, and improve standards of living.

The Lebanese private sector has traditionally been the dominant engine of growth in a relatively open and liberal economic environment, and its resilience has been invoked in the postwar context to lead the reemergence of Lebanon as a preeminent regional hub for trade and services. Capitalizing on its traditional strength in the banking and services segments, the private sector is rising to the challenge, but the constraints imposed by fiscal macroeconomic realities are real, and the scope for private sector maneuver seems limited at best. The private sector is equally constrained by an outdated legal and institutional governance framework, with the limited evidence available suggesting significant room for improvement in Lebanon's equity market - Lebanon's stock market capitalization is 15 per cent of GDP - as well as regulatory capacity and enforcement (Institute for International Finance, 2005).

\section{RESEARCH METHODOLOGY}

The research undertaken is interpretive in nature (Gephart, 2004), capitalizing on in-depth interviews with top managers of eight corporations operating in Lebanon to explore their interpretations in relation to CG, CSR, and their perceptions of the CG-CSR link. Interpretive research is qualitative, seeking to unearth collective frames of reference, or construed realities that guide the attribution of meaning and help account for how managers create, enact, or interpret the reality they inhabit (Isabella, 1990). To gain a better understanding of CG/CSR interpretations, it was deemed useful to seek viewpoints derived from managers involved in different types of organizations (e.g., Lebanese versus multinational, and shareholder versus family ownership). This diversified sample composition was deemed necessary to capture and detect differences in perceptions, practices, and interpretations between local managers and their international counterparts, as well as institutions with potentially differing CG and CSR dynamics. Our sample thus came to comprise eight medium and large companies operating in Lebanon, six of which are Lebanese owned, while two are subsidiaries of multinational corporations (Table 3).

Initial website screening provided a preliminary idea of the scope and sophistication of both CG and CSR in the context of a sample of Lebanese and multinational firms. Ten local firms and three subsidiaries of multinational corporations were subsequently contacted through phone and invited to participate in the research, taking into consideration both proximity and availability of personal contacts. Upon securing preliminary approval from six local companies and two MNCs, a cover letter explaining the nature and scope of the research, a copy of the interview guide, and an appointment scheduled within two weeks to conduct the 
TABLE 3

List of Organizations Included in Study

\begin{tabular}{|c|c|c|c|c|c|}
\hline Company name & Line of business & $\begin{array}{l}\text { Geographic } \\
\text { origin }\end{array}$ & $\begin{array}{l}\text { Geographic } \\
\text { reach }\end{array}$ & $\begin{array}{l}\text { Number of } \\
\text { employees }\end{array}$ & $\begin{array}{c}\text { Managers } \\
\text { interviewed }\end{array}$ \\
\hline $\begin{array}{l}\text { Standard Chartered } \\
\text { PLC }\end{array}$ & Banking services & Foreign & International & 5,000 & $\begin{array}{l}\text { - Head of Marketing } \\
\text { and Corporate } \\
\text { Affairs }\end{array}$ \\
\hline Aramex & $\begin{array}{l}\text { Express delivery, freight } \\
\text { forwarding, warehousing/ } \\
\text { distribution services }\end{array}$ & Foreign & International & 4,000 & - Country Manager \\
\hline $\begin{array}{l}\text { Société Nationale } \\
\text { d'Assurances }\end{array}$ & $\begin{array}{l}\text { Insurance, reinsurance/ } \\
\text { financial products }\end{array}$ & Lebanese & Regional & 120 & $\begin{array}{l}\text { - Head of Corporate } \\
\text { Communications }\end{array}$ \\
\hline $\begin{array}{l}\text { Lebanese Canadian } \\
\text { Bank SAL }\end{array}$ & Banking services & Lebanese & Local & 540 & $\begin{array}{l}\text { - Senior Manager, } \\
\text { Human Resources } \\
\text { and Accounting }\end{array}$ \\
\hline Albina SAL & $\begin{array}{l}\text { Wholesale of mechanical } \\
\text { and electrical material for } \\
\text { the construction sector }\end{array}$ & Lebanese & Regional & 75 & $\begin{array}{l}\text { - Owner and Chief } \\
\text { Executive Officer } \\
\text { - Finance Manager }\end{array}$ \\
\hline Medevco & $\begin{array}{l}\text { Wholesale and } \\
\text { distribution of public } \\
\text { works equipment }\end{array}$ & Lebanese & Local & 38 & $\begin{array}{l}\text { - Partner and CEO } \\
\text { - VP of Sales and } \\
\text { Operations }\end{array}$ \\
\hline Soliupak & $\begin{array}{l}\text { Manufacturer, } \\
\text { warehousing and } \\
\text { distribution of IV } \\
\text { solutions }\end{array}$ & Lebanese & Local & 50 & $\begin{array}{l}\text { - Deputy General } \\
\text { Manager, Business } \\
\text { Development }\end{array}$ \\
\hline Byblos Bank SAL & Banking services & Lebanese & International & 1,380 & $\begin{array}{l}\text { - Head of Corporate } \\
\text { Communications }\end{array}$ \\
\hline
\end{tabular}

interview was forwarded to managers. The interviews consumed on average two hours, were conducted primarily in English, tape-recorded, and subsequently transcribed and compiled in the form of a case study addressing CG, CSR, and their interfaces for each company. Each case study consisted of 10-15 pages of script on average.

The research made use of semi-structured interviews whereby an interview guide comprising three sections was developed, based on the literature review presented in the previous sections, addressing CG practices, CSR practices, in addition to CG-CSR relationships (Table 4). To gain a better understanding of managerial interpretations, it was deemed useful to seek viewpoints derived from managers involved in CG/CSR at different managerial levels. Accordingly, managers occupying different positions in these firms were contacted including those of CEOs, VPs, country managers, deputy general managers, senior accounting managers, and heads of corporate communications; our meetings hence solicited feedback from a total of 10 managers representing different hierarchical levels within their respective organizations as illustrated in Table 3. All interviewees had solid educational qualifications and international experience although demographic data was collected in brief as managers spoke mostly in the capacity of representatives of their respective organizations.
While the interview guide served the purpose of steering discussions around common themes, the semi-structured nature of interviews also left the interviewer to decide on the sequence/wording of questions in the course of the interview. Hence, the themes illustrated in Table 4 provided a common stimulus around which interpretive comparisons could be made, with the option available to explore in more depth areas of significance to particular interviewees. While some of the questions yielded factual information (e.g., ownership structure, composition of board of directors), others allowed significant room for interpretation (e.g., motives for good CG; principles motivating CSR). The last section of the interview was devoted to a discussion of the different potential interrelationships between CG and CSR as per our three models presented earlier, leaving questions there openended to capture to the fullest managerial interpretations in relation to CG-CSR interfaces.

Following the transcription of the interviews and the compilation of case studies, a joint analytical effort involving all three authors focused on detecting commonalities or patterns of agreement/convergence in the statements provided in relation to the basic dimensions outlined in Table 4; areas of divergence were equally noted, debated, and highlighted. The analysis of the data collected in the last section of the interview regarding conceptions of the link between 
TABLE 4

Topics Addressed in Interviews

I. Corporate governance (CG)

Ownership structure

Composition of board of directors

Board of director committees

Codes of conduct codes of governance

Executive compensation schemes

Required disclosure

Motives for good CG practice

II. Corporate social responsibility (CSR)

Conception of CSR

CSR activities

Formality of CSR program

CSR values

Principles motivating CSR

Anticipated benefits of CSR

Most important stakeholders

Measurement of CSR

III. Conception of CG/CSR relationship

CG pillar of CSR

CSR dimension of CG

CG-CSR part of continuum

CG and CSR followed a grounded theory approach as formulated by Glaser and Strauss (1967), involving a comparison of the data with theory (presented in our models) throughout the data collection/analysis process. Theory helped direct attention to important dimensions while the actual data collected helped shed light simultaneously on the theory's suitability in light of the data being collected (Isabella, 1990). The result of this fluid movement between theory and data is, according to Isabella (1990), very fruitful in way of reconceptualization and accounting for all nuances in the data. In this respect, points that participants tended to repeat served to augment the evolving theory (Isabella, 1990).

In the framework of the methodology outlined above, we present our main findings in the following sections. The findings are aggregated where feasible, with convergence and divergence highlighted at every turn, while relevant excerpts are also extracted verbatim to illustrate specific points when discussing the main findings. The identities of the managers are, however, concealed for confidentiality and anonymity reasons. As illustrated below, the interviews provided interesting and fruitful insights regarding CG, CSR, and CG-CSR relationships and interfaces, based on managerial conceptions and practical interpretations.

\section{RESEARCH FINDINGS}

\section{Assessment of CG Practices}

We obtained interesting feedback about current CG practices, generally indicating awareness of and engagement with CG issues and what they entail. All interviewees discussed various aspects of CG that are commonly integrated in the practice of their respective firms, with the most frequently discussed aspects revolving around compliance, transparency, and disclosure. While firms in our sample exhibited different ownership structures involving large, small, and institutional shareholders as well as familyowned structures (please see Table 5), they mostly had independent directors (five out of eight), and board of directors committees (four out of eight). In half the cases, the chairman of the board of directors also acted as the CEO (four out of eight). The majority of firms had formulated a remuneration policy for board members and key executives, highlighting the link between remuneration and performance (six out of eight). The majority of the firms had codes of conduct in place (seven out of eight), and all stressed on the importance of required disclosure and the regular review of internal controls (eight out of eight).

The reported strength in current CG practices revolved around the strategic guidance exercised by boards, and their regular oversight of internal control mechanisms. All managers mentioned the regular use of audit committees to oversee the company's disclosure practices. There was a mention in two cases (local firms) of boards taking on dayto-day operational responsibilities rather than focusing on long-term strategic issues. Three managers described their company boards as either passive "rubber stamps" or as active participants in furthering the interests of only controlling shareholders. Several managers also mentioned in confidence problems arising from concentrated ownership, weak shareholder protection, insufficient disclosure, or a combination of these factors. All the interviewees generally shared the view that the emphasis in their CG practice is on ensuring compliance with laws and regulations, establishing codes of conduct, and the oversight of internal control systems for financial reporting. Generally, the control facet of GG was certainly more emphasized in the discussions held than the strategic leadership component.

Comparing the CG practices of foreign companies to those of their local counterparts, we noticed that the two subsidiaries of international firms in our sample separated between the position of CEO and chairmanship of the board, which was not the case for most of their local counterparts. We also noted more transparency on their part regarding the process of staffing boards and the configuration of remuneration for board members and key executives. The declared motives for the adoption of sound CG practices revolved around consistency with mother firm practice and compliance with international standards. Local companies claimed, on the other hand, that a major incentive for them to adopt sound CG norms and principles stemmed from the requirements of international certification (e.g., ISO), and also to keep up with the requirements of global competitiveness (e.g., Basel II requirements). Several of the local companies, however, admitted outstanding problems in way of CG implementation, stemming from macroeconomic instability and the very limited vigilance and capacity of the regulatory and judicial systems in the country. 


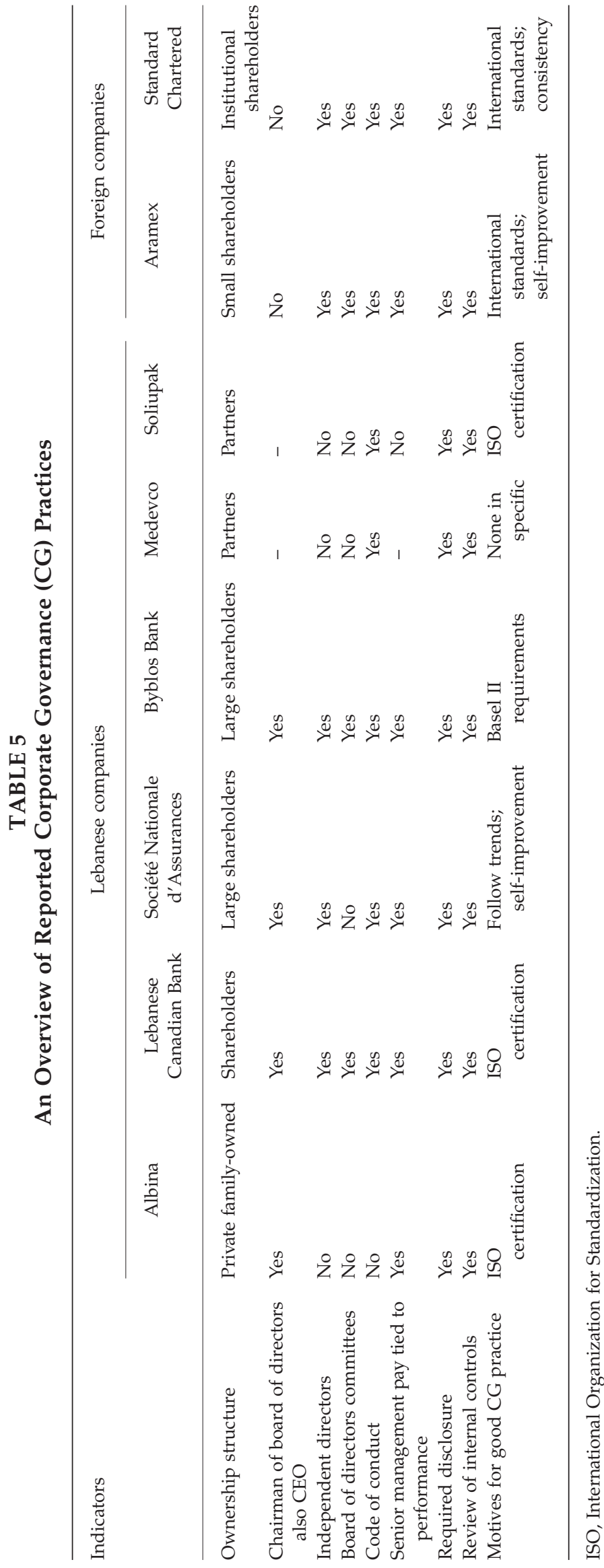

\section{Assessment of CSR Practices}

We also obtained interesting feedback regarding the current CSR practices of our sampled firms. All the managers interviewed adhered to a voluntary action or philanthropic type conception of CSR (Table 6). When asked about the type of CSR performed, all managers consistently referred to philanthropic activities and programs revolving mainly around philanthropic donations and ranging from the sponsoring of scholarships and events to donations/programs involving the orphans or handicapped, to volunteering and promoting good working conditions. The majority of local companies (five out of six) had no formal CSR program in place and no specific CSR values, with their philanthropic CSR activity rooted in most cases in principles of legitimacy and generalized community commitments.

When asked about the principles motivating CSR behavior, most managers mentioned the principle of legitimacy and the principle of managerial discretion. As noted by several of the managers interviewed, legitimacy is generally conceived as a license for continued operation and appreciation by society, despite the conspicuous absence of specific institutionalized expectations. Hence, as illustrated in Table 6, all the managers interviewed - with no exception - mentioned the importance of maintaining legitimacy and credibility in a shared environment, and providing their share of reciprocal benefits and investments. Four managers also mentioned the principle of managerial discretion in the sense that their firm's CSR orientation has been molded by the philanthropic values and enlightened entrepreneurship exercised by founders, owners, or top managers of the enterprise.

In relation to the distinction between internal and external CSR, the external dimension of CSR was clearly emphasized by all the managers interviewed, with all the managers referring to customers as the most important external stakeholder, followed by the community stakeholder. This reflects an overall instrumental approach to CSR, which is nuanced by normative flavors vis-à-vis the community stakeholder. The internal dimension of CSR and relevant issues there pertaining to health, safety, training, and working conditions were in turn mentioned by four of the managers interviewed (two local firms and two international), and employees were classified as the second most important stakeholder in the majority of cases (six out of eight). Generally, stakeholders seem to be considered important when they represent rational or economic motives for the firm.

The instrumental approach to CSR is further illustrated through the reflections obtained on the anticipated benefits of CSR, with the managers of local firms focusing primarily on issues relating to differentiation, enhanced reputation, legitimacy, and recognition in the community. Interestingly, the managers of international firms accorded equal attention to the potential internal benefits of CSR involvement as reflected in increased employee satisfaction and enhanced innovation. A sense of enlightened self-interest was detected among the majority of the managers in the sense that they appreciated the short-term and long-term benefits of CSR, particularly in terms of increasing the credibility and trustworthiness of the firm in the eyes of internal and external stakeholders. 


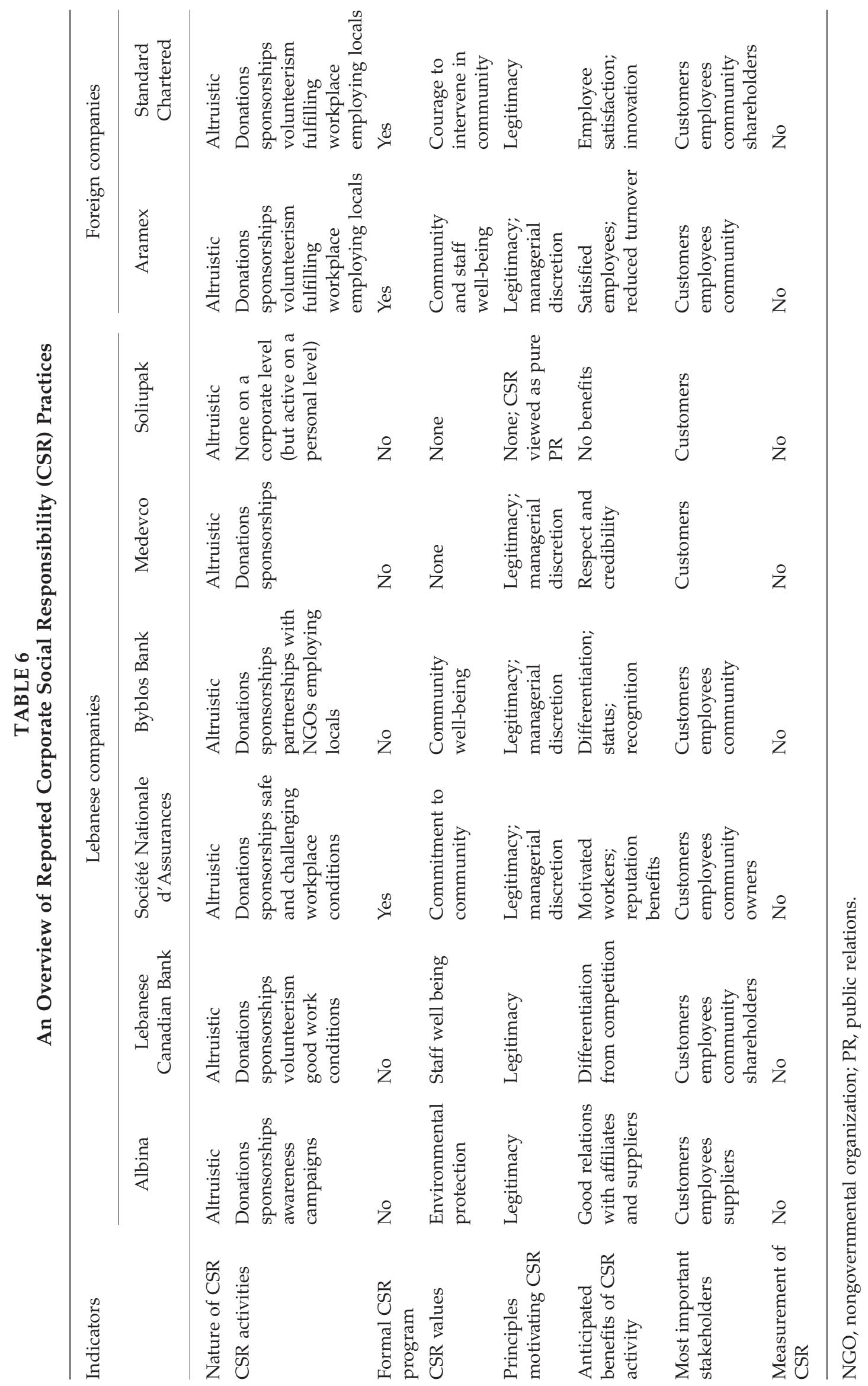


TABLE 7

An Assessment of the CG-CSR Link

Indicators

Lebanese companies

Foreign companies

\begin{tabular}{|c|c|c|c|c|c|c|c|}
\hline Albina & $\begin{array}{c}\text { Lebanese } \\
\text { Canadian } \\
\text { Bank }\end{array}$ & $\begin{array}{c}\text { Société } \\
\text { Nationale } \\
\text { d'Assurances }\end{array}$ & $\begin{array}{c}\text { Byblos } \\
\text { Bank }\end{array}$ & Medevco & Soliupak & Aramex & $\begin{array}{l}\text { Standard } \\
\text { Chartered }\end{array}$ \\
\hline
\end{tabular}

\begin{tabular}{lcccccccc}
\hline CG pillar of CSR & Yes & Yes & - & - & Yes & Yes & Yes & - \\
CSR as a dimension of CG & - & - & - & Yes & - & - & - & - \\
CG-CSR continuum & - & - & Yes & - & - & - & - & Yes \\
Model embraced & 1 & 1 & 3 & 2 & 1 & 1 & 1 & 3 \\
\hline
\end{tabular}

CG, corporate governance; CSR, corporate social responsibility.

None of the companies interviewed measure systematically the social impacts of their CSR interventions, and the findings suggest that corporate social reporting has not picked up momentum in the Lebanese context. The companies interviewed indeed seem to be according no attention to social assessment devices, such as social indicators or the social balance sheet. Despite this trend, and the possibility of a spontaneous social desirability bias in the context of CSR research, the managers provided valid and concrete examples of CSR initiatives, as in charity donations and/or specific donations to the Lebanese Red Cross, sponsorships and educational scholarships, environmentally friendly technology, and partnerships with NGOs in pursuit of social goals. These were invariably fleshed out with reference to concrete investments and examples.

In way of comparing the conceptions and practices of Lebanese and foreign companies, only one local Lebanese company has a formal CSR program, whereas the CSR programs of the two multinational firms seem to have been institutionalized. Most local companies seem to have also made only modest progress in way of formalizing their CSR values or integrating CSR into daily operations and decisionmaking processes. While the subsidiaries of multinational corporations also have maintained an altruistic approach to CSR and had vaguely formulated values, they have made significant strides in way of setting specific budgets and themes for their local CSR programs. They are thus more sophisticated in their approach and more at ease in communicating their CSR strategies and programs.

\section{Assessment of the CG-CSR Link}

We obtained in turn varied reflections on the nature of the CG-CSR relationship from managers, based on their actual practice and interpretation, which are illustrated in Table 7.

Five of the respondents share the view that a company cannot have a genuine CSR orientation, if it does not have a solid CG pillar in place. It is essential, according to these interviewees, to lay the necessary infrastructure in way of strategic leadership and good control systems, in order for the firm to benefit its owners and internal/external stakeholders. These views lend support to the Hancock (2005) postulation (model \# 1). Two of the respondents argued that CG and CSR are two facets (internal and external) of commitment to sound business conduct and that they should be integrated into the same spectrum or continuum of corporate disclosure. The argument advanced by these managers is that CG and CSR are indeed complementary and mutually reinforcing in the sense that an effective CG structure protects shareholders from unlawful action while an effective CSR program prevents various actions which may be legal but inappropriate in relation to their impact or implications for specific constituencies/stakeholders. Hence, we could detect some support for the Bhimani and Soonawalla's (2005) model examined earlier (model \# 3). Only one of the local managers/respondents interviewed considered CSR as a dimension or attribute of CG as per model 2. According to this view, good CG also entails ensuring that companies are run in a socially responsible way. In a way, this is a more sophisticated conception of CG that considers CSR as an integrated mandatory aspect or dimension of good governance. Based on our excursion in this paper, and accumulated reporting evidence, it is clear that most firms still conceive of CSR as optional and discretionary rather than as an integrated/mandatory attribute of CG. We have thus encountered limited support for this conception in our sample, and we expect this to be more widely shared.

\section{DISCUSSION OF FINDINGS AND THEORETICAL PROPOSITIONS}

The findings are discussed critically in this section in way of fleshing further relevant insights and identifying concrete theoretical implications. In relation to $C G$, the interviews conducted and managerial interpretations clearly suggest the prevalence of mainstream CG in the Lebanese context, dominated by the traditional neoclassical view, coupled with an emphasis on the control and compliance aspects of CG. Our findings suggest that the pressures for convergence are salient, and particularly felt by the large multinational firms. As articulated by one of the managers "we are continuously adapting our CG practices in line with the dominant international model given the integration of financial 
markets and pressures from our international institutional investors." Awareness of international codes of good governance was, however, counterbalanced and nuanced by an appreciation among the majority of managers interviewed (particularly local ones) that CG needs to be considered in context, and that CG practices are invariably influenced and molded by national institutional environments, and cultural, economic, and sociopolitical constellations. "CG practices need to take account of differences in culture, political tradition, financing options, corporate ownership patterns and legal and regulatory environments" as noted by one of the local managers. Divergence from best practice was invariably interpreted and justified in this context, as in the failure to pursue a dual strategic leadership pattern in some cases, or problems arising from concentrated ownership, weak shareholder protection, or insufficient disclosure. Various managers also noted constraints stemming from macroeconomic instability and the very limited vigilance and capacity of the regulatory and judicial systems in the country. According to one of the managers, "while it is difficult to undermine the benefits of integrating best CG practices, there are many hurdles, stemming from existing rules and regulations that are neither exhaustive nor properly enforced, regulatory bodies that are incapable of inspecting complaints and violations, and a largely incompetent judicial system." Our findings thus highlight the salience of the sociopolitical view of CG as suggested by prior research (Aguilera and Jackson, 2003; Gordon and Roe, 2004: Aguilera et al., 2006; Zattoni and Cuomo, 2008), translating into our first theoretical proposition:

Proposition 1: Despite convergence pressures arising from globalization, local socio-politico-institutional environments significantly affect CG practices in developing countries.

In relation to CSR, our findings suggest the prevalence of a philanthropic conception of CSR among the managers interviewed. This orientation is mostly rooted in religious principles in the Lebanese context as noted in previous studies (Jamali, Zanhour and Keshishian, 2008), although this connection was difficult to establish in this research given that it was not explored in depth. An instrumental CSR orientation was detected among the majority of the managers interviewed, translating into an enlightened selfinterest and concern with long-term value maximization (Jensen, 2002), and an interim focus on traditional stakeholders, including customers, employees, and shareholders. As noted by one of the local managers, "our objective is to attend to the needs of our customers and employees, which in the long run implies greater value creation for our owners and shareholders." Some local managers explicitly admitted their concern with the anticipated benefits of CSR, particularly with the strong corporate branding and enhanced public image that are by-products of CSR adoption, while others echoed a more sophisticated stakeholder orientation, nuanced by normative flavors particularly in relation to the community stakeholder. As expressed by one of the managers, "we seek to nurture a wide spectrum of trust based stakeholder relationships, which can serve as a source of opportunity and competitive advantage." Another manager expressed the view that "we realize that we operate within a bounded space and that giving back to the community is paramount." The natural environment was conversely accorded the least attention among managers in our sample, suggesting in turn that ecological sustainability does not constitute an integral part of managerial interpretations of CSR and that triple bottom line integration remains a distant aspiration. Various managers noted in this respect limited institutional pressures for CSR in their local context, particularly in relation to the environmental dimension and expressed a desire for more active involvement on the part of governments and NGOs. These findings combine to explain the limited sophistication of CSR conception among local managers, the continued prevalence of philanthropic CSR, and a gap between CSR rhetoric and reality in developing countries as suggested by previous research (Jamali and Mirshak, 2007; Jamali, 2008), leading to our second proposition:

Proposition 2: Limited institutional pressures for homogenization in CSR translate into philanthropic and instrumental CSR orientations in developing countries.

We turn here to analyze the third and most important component of this research relating to CG-CSR links and interfaces. Our findings reveal a predominant interpretation of CG as a pillar of CSR among managers (consistent with model \#1), suggesting conceptions of CSR as necessarily anchored in a strong CG foundation. In the words of one manager, "a company can not apply a stand alone CSR program, if it does not first instill a credible robust, trust engendering, accountability setting, rights protecting CG framework." Several managers aptly communicated in this respect that the nature of a firm's CG invariably persuades managers and executives to emphasize particular goals and objectives in relation to CSR and that company boards are accordingly key participants in ensuring companies do promote and meet CSR standards. Consistent with the views of Elkington (2006), CSR is thus conceived by the majority of the managers interviewed as a board responsibility, or, as aptly suggested by one manager, as "the outward expression of a Board's CG policies." One manager summed it up nicely in these words "the external CSR pulse is invariably framed in the context of sound and effective CG policies." That CSR needs to be anchored in a strong CG pillar and polices and needs to be increasingly considered as part of the responsibility of company boards has also received support in prior research (e.g., Mahoney and Thorne, 2005; Mackenzie, 2007; Parsa, Kouhy and Tzovas, 2007). This leads to our third theoretical proposition:

Proposition 3: Good CG is increasingly considered in developing country contexts as a necessary foundational pillar for a genuine and sustainable CSR orientation.

Our findings finally suggest some interpretations among the managers interviewed of CG and CSR as complementary and coexisting components of the same accountability continuum. The difference between the two ends of the continuum as expressed by one of the managers is that "with CG, we are practically applying the letter of the law, whereas CSR represents the spirit of the law." In other words, while CG standards and conformance may be required to ensure protection from abuses, this cannot replace a general sense of responsibility in business that goes beyond the letter 
FIGURE 4

CG and CSR Interfaces

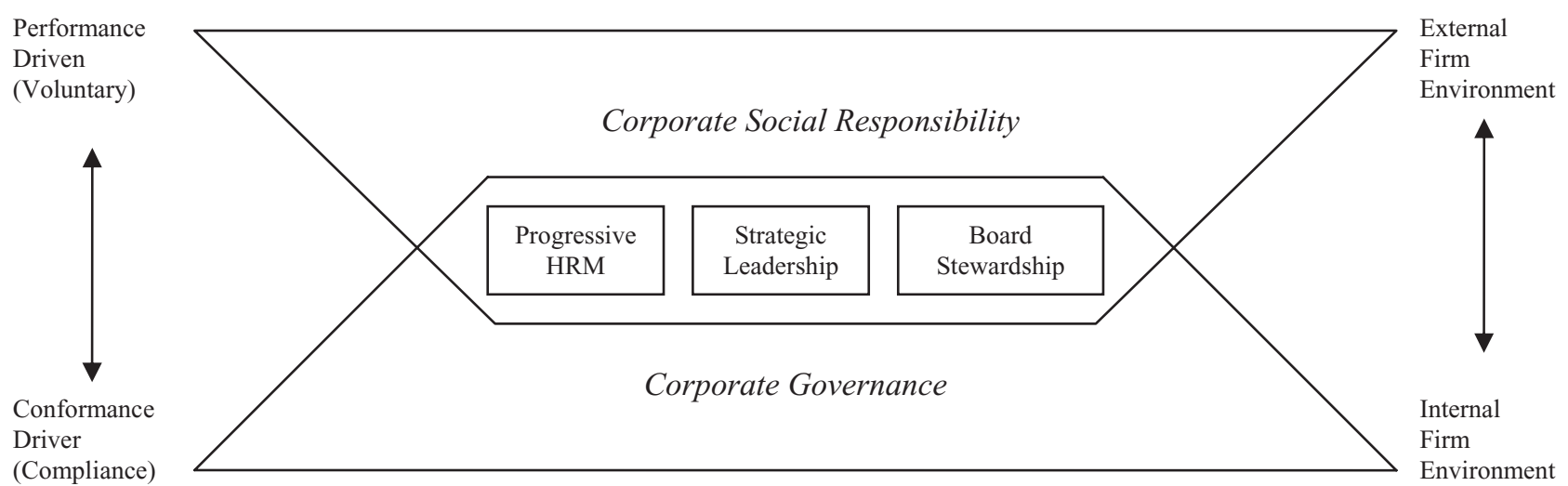

of the law as illustrated in voluntary social performance. The same analogy was echoed by another manager who expressed that "CG is the way you run your business, while CSR effectively represents its conscience." The same manager expressed that "CSR is a self-regulating form of governance, it is not legally binding, but morally guiding." Two managers observed increasing concern with the right end of the continuum, going beyond legal conformance to tackle initiatives consistent with voluntary corporate social performance. As summarized by one manager, "while the role of CG in establishing accounting standards and a framework of accountability can not be discounted, we are increasingly trying to adopt commitments to wider forms of social and environmental engagement and reporting, as reflected in corporate performance on the right end of the continuum." These observations combine to suggest that firms are increasingly expected to address CG and CSR issues hand in hand, and to move beyond conformance or compliance to voluntary performance, which is also supported by previous research (e.g., Marsiglia and Falautano, 2005; Clarke, 2007), leading to our fourth proposition:

Proposition 4: The ascendancy and taken-for-grantedness of good CG in developing economies is increasingly complemented by due regard and consideration for voluntary corporate social performance.

Based on the research presented in this paper, and on the insights derived through the empirical component and discussions with managers, we propose a model that summarizes the main interfaces of CG and CSR (Figure 4). Our model reconciles the main contributions of the three models presented earlier. The model illustrates our starting assumption in this paper that CG and CSR are two sides of the same coin (as per Bhimani and Soonawalla, 2005). Second, it posits CG as a necessary foundational pillar or building block for CSR as per Hancock (2005). Third, it illustrates the crossconnects between CG and CSR revolving around strategic leadership and stewardship as implied in Ho's (2005) postulation (reiterating in this respect the point that CSR is equally the responsibility of corporate boards) while also capturing the overlap between CG and the internal dimension of CSR revolving primarily around progressive human resource management (as in Table 2). Finally, our model suggests that while CG is increasingly conformance or compliance driven, CSR falls on the other hand in the realm of voluntary social performance as per Bhimani and Soonawalla (2005).

Reflecting further on the wider implications of this research, our findings posit some challenges to agency theory, suggesting increasing convergence between the views of both principals and agents regarding a widened stakeholder approach, reconciling basic principles of CG and CSR. This can be safely drawn from the interviews we conducted generally, but two of the interviews specifically involved both shareholders and managers, who seemed in agreement regarding a systematic and balanced attention to all stakeholders in the context of a sound CG framework and a wider CSR orientation. Thus, the tension between fiduciary responsibility and the responsibility to a wider spectrum of stakeholders or what is referred to as the stakeholder paradox (Freeman, 1984) is not as salient as often assumed. Stakeholder theory seems to provide the flexibility for coping with the demands of a broadened CG/CSR agenda, even at the expense of increasing agency costs as per Jensen (2002).

Our findings lend support to institutional theory, suggesting that convergence in the context of both CG and CSR is often undermined by local socio-politico-economic constraints in developing countries. Despite familiarity with international CG and CSR codes and principles, the majority of managers reported serious hurdles in way of best practice implementation stemming from both internal and external environments. This translated into an accentuated emphasis on internal CG mechanisms to offset perceived weaknesses in legal and judicial structures, but challenges were reported in the internal domain as well, suggesting that global convergence toward a single Anglo-American model of governance is more protracted and complicated than often assumed (e.g., Hansmann and Kraakman, 2001). These findings are consistent with what is reported by Khanna, Kogan and Palepu (2002) of no evidence of convergence in CG practice with the advent of globalization, aside from the adoption of general CG recommendations, which are, in turn, not widely implemented. 
Our findings finally suggest significant linkages between the two ascending fields of CG and CSR. Both disciplines have attracted increasing attention in the context of globalization and escalating demands for greater accountability by companies. This research has made it clear that those two disciplines share more in common than previously assumed and that these interfaces are also increasingly appreciated by managers in the context of their actual practice and interpretation. Appreciation for those synergies and interdependencies has certainly been detected in this study and is deserving of further scrutiny and consideration in other contexts. While CG was generally conceived as establishing a basic framework of stewardship and trusteeship, CSR was conceived as the outward expression or manifestation of internal CG policies and principles.

\section{CONCLUDING REMARKS}

In researching the nature of the CG-CSR relationship, this paper has surveyed the literature and explored the perceptions and interpretations of CG and CSR in Lebanon. The first conclusion that can be safely drawn is that CG and CSR should not be considered and sustained independently. Irrespective of the type of relationship that exists between CG and CSR, a company without an efficient long-term view of leadership, effective internal control mechanisms, and a strong sense of responsibility vis-à-vis internal stakeholders cannot possibly pursue genuine CSR. CSR interventions risk being taken for public relations attempts particularly when the CSR orientation is not rooted in the context of a solid internal CG foundation. Conversely, CG is not entirely effective without a sustainable CSR drive because a company has to respond to the needs of its various stakeholders in order to be profitable and create value for its shareholders/owners. These observations suggest in turn that the link between CG and CSR is unequivocally a salient two-way relationship.

Our interpretive research in the Lebanese context suggests that most respondents appreciate the increasing convergence between CG and CSR, with the view that the more robust the CG framework in place, the more likely the evolution toward a sustainable CSR drive. In this respect, our findings support the insights of Elkington (2006) that the CSR agenda is progressively an extension of the CG agenda and is the responsibility of corporate boards. As noted in this paper, the nature of a firm's CG sets the overall tone for the organization, and can be used to entice executives to pursue specific goals and objectives in the CSR domain. In light of this empirical investigation, we have put forth a number of theoretical propositions that can serve to guide further research on the topic, suggesting importantly that CG is a necessary pillar for a genuine and sustainable CSR orientation and that the ascendancy and taken-for-grantedness of CG is increasingly complemented in developing countries by due regard for voluntary CSR performance.

Reflecting further on the theoretical and practical implications of this study, our findings challenge the usefulness of agency theory as the dominant paradigm in CG research in favor of stakeholder theory. The managers interviewed seemed less concerned about the importance of CG mecha- nisms in reducing agency costs, than they were about creating stakeholder value in the wider sense. Stakeholder theory indeed seems to be a promising theoretical lens for future research relating to CG-CSR interfaces. Moreover, the findings suggest that institutional theory could provide fruitful insights when exploring patterns of global convergence in CG and CSR research. Our findings indeed support the path dependence hypothesis in the context of CG and CSR, suggesting that national history trajectories and specific institutional constellations stand as potential barriers to convergence in the CG and CSR domains.

Further research can seek to shed light on the diffusion of CG and CSR, particularly in developing countries, and the multifaceted nature of CG and CSR and their complex interfaces. There is room in this respect for research on the interplay of internal and external CG mechanisms in specific institutional contexts and how these reflect in turn and mold peculiar CSR orientations. There is also room for research on the largely voluntary accountability paradigm advocated in the context of CSR, and how this agenda can be reconciled with agency theory. Of particular interest is the trend to articulate international standards and obligations in the CSR domain and how these potentially cross-connect with international CG codes and principles.

While this paper has provided fruitful initial insights into CG-CSR interfaces from a developing country perspective, the research, admittedly, has a number of limitations. The findings stem from a single-country investigation. This, combined with the small sample size (eight companies), may imply that the results cannot be readily generalized, although they are likely to have wider relevance and applicability, particularly in developing countries. The evidence gathered is also based on self-reporting, given the qualitative interpretive approach adopted, hence raising the possibility of a potential social desirability response bias. Social desirability response bias has indeed been noted to be particularly salient in the context of developing and collectivist economies (Bernardi, 2006).

Notwithstanding these limitations, we believe this study makes important contributions and constitutes a significant advancement in CG-CSR research. The study indeed has explored relatively new ground by investigating CG and CSR conceptions and applications in developing countries as well as interpretations of CG-CSR interfaces, suggesting that both CG and CSR need to be considered as complementary pillars for sustainable business growth in a globalizing environment. Our research, moreover, challenges the hegemony of agency theory as the dominant paradigm in CG and CSR research, highlighting in turn the usefulness of alternative stakeholder and institutional theoretical lens in accounting for a complex blend of normative and instrumental motivations and orientations in developing country contexts. These initial trends can hopefully be further explored and validated through future research on the topic.

\section{REFERENCES}

Aguilera, R. and Jackson, G. (2003) The cross-national diversity of corporate governance: Dimensions and determinants, Academy of Management Review, 28: 447-65. 
Aguilera, R., Rupp, D. and Ganapathi, J. (2007) Putting the S back in corporate social responsibility: A multilevel theory of social change in organizations, Academy of Management Review, 32: 83663.

Aguilera, R., Williams, C., Conley, J. and Rupp, D. (2006) Corporate governance and social responsibility: A comparative analysis of the UK and the US, Corporate Governance: An International Review, 14: 147-58.

Barnett, M. (2007) Stakeholder influence capacity and the variability of financial returns to corporate social responsibility, Academy of Management Review, 32: 794-816.

Barney, J. (2007) Looking inside for competitive advantage. In: Schuler, R. and Jackson, S. (eds.) Strategic Human Resource Management. Blackwell Publishing, Oxford.

Beltratti, A. (2005) The complementarity between corporate governance and corporate social responsibility, Geneva Papers on Risk $\mathcal{E}$ Insurance, 30: 373-86.

Bernardi, R. (2006) Associations between Hofstede's cultural constructs and social desirability response bias, Journal of Business Ethics, 65: 43-53.

Bhimani, A. and Soonawalla, K. (2005) From conformance to performance: The corporate responsibilities continuum, Journal of Accounting and Public Policy, 24: 165-74.

Business for Social Responsibility (BSR) (2003) Overview of Corporate Social Responsibility. (http://www.bsr.org/ BSRResources/WhitePaperDetail.cfm?DocumentID=48809).

Cadbury, A. (2000) The corporate governance agenda, Journal of Corporate Governance, Practice-Based Papers, 8: 7-15.

Carroll, A. (1979) A three-dimensional conceptual model of corporate performance, Academy of Management Review, 4: 497-505.

Carroll, A. B. (1991) The pyramid of corporate social responsibility: Toward the moral management of organizational stakeholders, Business Horizons, 34: 39-48.

Clarke, T. (2007) The evolution of directors' duties: Bridging the divide between corporate governance and corporate social responsibility, Journal of General Management, 32: 79-105.

Deakin, S. and Hobbs, R. (2007) False dawn for CSR: Shifts in regulatory policy and the response of the corporate and financial sectors in Britain, Corporate Governance: An International Review, 15: $68-76$

Denis, D. and McConnell, J. (2003) International corporate governance, Journal of Financial and Qualitative Analysis, 38: 1-36.

Dunlop, A. (1998) Corporate Governance and Control, CIMA Publishing, London.

Elkington, J. (2006) Governance for sustainability, Corporate Governance: An International Review, 14: 522-29.

Freeman, E. (1984) Strategic Management: A Stakeholder Approach, Pitman Publishing, Boston.

Gephart, R. (2004) Qualitative research and the Academy of Management Journal, Academy of Management Journal, 47: 454-62.

Glaser, B. and Strauss, A. (1967) Discovery of Grounded Theory: Strategies for Qualitative Research, Aldine, Chicago.

Gompers, P., Ishii, J. and Metrick, A. (2003) Corporate governance and equity prices, Quartery Journal of Economics, 118: 107-55.

Gordon, N. and Roe, J. (2004) Introduction. In: Gordon, J. and Roe, M. (eds.) Convergence and Persistence in Corporate Governance, 1-30. Cambridge University Press, Cambridge.

Grosser, K. and Moon, J. (2005) Gender mainstreaming and CSR: Reporting workplace issues, Journal of Business Ethics, 62: 327-40.

Hancock J. (ed.) (2005) Investing in Corporate Social Responsibility: A Guide to Best Practice, Business Planning \& the UK's Leading Companies, Kogan Page, London.

Hansmann, H. and Kraakman, R. (2001) The end of history for corporate law, Georgetown Law Journal, 89: 439-68.

Hardjono, T. W. and van Marrewijk, M. (2001) The social dimensions of business excellence, Corporate Environmental Strategy, 8: 223-33.
$\mathrm{Hg}, \mathrm{M}$. (2007) An essay on social responsibility and the limits of the corporate form: A perspective on environmental protection, Journal of Environmental Law and Practice, 17: 115-39.

Ho, C. (2005) Corporate governance and corporate competitiveness: An international analysis, Corporate Governance: An International Review, 13: 211-53.

Huse, M. (2005) Accountability and creating accountability: A framework for exploring behavioral perspectives of corporate governance, British Journal of Management, 16: 65-79.

Institute for International Finance, Inc (IIF) (2005) Corporate Governance in Lebanon - An Investor Perspective. Task Force Report, IIF Equity Advisory Group, Washington.

Isabella, L. (1990) Evolving interpretations as a change unfolds: How managers construe key organizational events, Academy of Management Journal, 33: 7-41.

Jamali, D. (2006) Insights into triple bottom line integration from a learning organization perspective, Business Process Management Journal, 12: 809-21.

Jamali, D. (2007) The case for strategic corporate social responsibility in developing countries, Business and Society Review, 112: $1-27$.

Jamali, D. (2008) A stakeholder approach to corporate social responsibility: Fresh insights into theory vs practice, Journal of Business Ethics (in press).

Jamali, D. and Mirshak, R. (2007) Corporate social responsibility: Theory and practice in a developing country context, Journal of Business Ethics, 72: 243-62.

Jamali, D., Zanhour, M. and Keshishian, T. (2008) Peculiar strengths and relational attributes of SMEs in the context of CSR, Journal of Business Ethics (in press).

Jensen, M. (2002) Value maximization, stakeholder theory, and the corporate objective function, Business Ethics Quarterly, 12: 235-56.

Jesover, F. and Kirkpatrick, G. (2005) The revised OECD principles of corporate governance and their relevance to non-OECD countries, Corporate Governance: An International Review, 13: 12736.

Jones, P., Comfort, D. and Hillier, D. (2005) Corporate social responsibility and the UK's top ten retailers, International Journal of Retail and Distribution Management, 33: 882-92.

Keasy, K. and Wright, M. (1997) Corporate Governance - Responsibilities, Risks and Remuneration, John Wiley \& Sons, New York.

Kendall, N. (1999) Good corporate governance, Accountants' Digest. Issue 40. The ICA in England and Wales.

Khanna, T., Kogan, J. and Palepu, K. (2002) Globalization and Corporate Governance Convergence? A Cross-Country Analysis. Working Paper, Harvard Business School.

Lantos, G. (2001) The boundaries of strategic corporate social responsibility, Journal of Consumer Marketing, 18: 595-630.

La Porta, R., Lopez de Silanes, F., Shleifer, A. and Vishny, R. (1998) Law and Finance, Journal of Political Economy, 106: 1113-55.

Mackenzie, C. (2007) Boards, incentives and corporate social responsibility: The case for a change of emphasis, Corporate Governance: An International Review, 15: 935-43.

MacMillan, K., Money, K., Downing, S. and Hillenbrad, C. (2004) Giving your organization SPIRIT: An overview and call to action for directors on issues of corporate governance, corporate reputation and corporate responsibility, Journal of General Management, 30: 15-42.

Mahoney, L. and Thorne, L. (2005) Corporate social responsibility and long-term compensation: Evidence from Canada, Journal of Business Ethics, 57: 241-53.

Mallin, C. (2005) Corporate governance: A review of some key developments, Corporate Governance: An International Review, 13: 107.

Margolis, J. and Walsh, J. (2003) Misery loves companies: Revisiting social initiatives by business, Administrative Science Quarterly, 48: 268-305. 
Marsiglia, E. and Falautano, I. (2005) Corporate social responsibility and sustainability challenges for a Bancassurance Company, The Geneva Papers, 30: 485-97.

Munilla, L. S. and Miles, M. P. (2005) The corporate social responsibility continuum as a component of stakeholder theory, Business and Society Review, 110: 371-87.

Organization for Economic Cooperation and Development (OECD) (1999) Measuring and Reporting Intellectual Capital: Experiences, Issues, and Prospects, OECD, Paris.

Page, J. P. (2005) Corporate Governance and Value Creation. University of Sherbrooke, Research Foundation of CFA Institute.

Parsa, S., Kouhy, R. and Tzovas, C. (2007) Governance and social information disclosure - Evidence from the UK, International Journal of Business Governance and Ethics, 3: 205-22.

Perrini, F., Pogutz, S. and Tencati, A. (2006) Developing Corporate Social Responsibility: A European Perspective, Edward Elgar Publishing, Cheltenham, Gloucestershire.

Post, E., Preston, E. and Sachs, S. (2002) Managing the extended enterprise: The new stakeholder view, California Management Review, 45: 6-28.

Quester, P. and Thompson, B. (2001) Advertising and promotion leverage on arts sponsorship effectiveness, Journal of Advertising Research, 41: 33-47.

Rosam, I. and Peddle, R. (2004) Implementing Effective Corporate Social Responsibility and Corporate Governance, British Standards Institution, UK.

Saidi, N. (2004) Corporate Governance and Business Ethics in Lebanon. Keynote speech on occasion of the launch of the RDCL Code of Business Ethics, Beirut, Lebanon.

Saravanamuthu, K. (2004) What is measured counts: Harmonized corporate reporting and sustainable economic development, Critical Perspectives on Accounting, 15: 295-302.

Tricker, R. (1994) International Corporate Governance: Text, Readings and Cases, Prentice Hall, New Jersey.

Van den Berghe, L. and Louche, C. (2005) The link between corporate governance and corporate social responsibility in insurance, The Geneva Papers, 30: 425-42.

WBCSD (World Business Council for Sustainable Development) (2001) The Business Case for Sustainable Development: Making a Difference toward the Johannesburg Summit 2002 and Beyond, WBCSD, Switzerland.

Windsor, D. and Preston, L. (1988) Corporate Governance, Social Policy and Social Performance in the Multinational Corporation, Research in Corporate Social Performance and Policy, 10: 45-58.

Wright, P., Dunford, B. and Snell, S. (2007) Human resources and the resource-based view of the firm. In: Schuler, R. and Jackson, S. (eds.) Strategic Human Resource Management. Blackwell Publishing, Oxford.
Zattoni, A. and Cuomo, F. (2008) Why adopt codes of good governance? A comparison of institutional and efficiency perspectives, Corporate Governance: An International Review, 16: 1-15.

Dr. Dima Jamali is a Senior Lecturer in the School of Management, University of Southampton and is an Associate Professor in the School of Business, American University of Beirut. She holds a PhD in Social Policy and Administration from the University of Kent at Canterbury, UK. Her research interests encompass corporate social responsibility as well as gender and careers. She worked as an expert consultant on projects funded by the World Bank, the US Agency for International Development, NGOs, and other regional and local public and private firms. She is the author of numerous papers in international peer-reviewed journals, including Corporate Governance: An International Review, Journal of Business Ethics, Business Process Management Journal, and Women in Management Review.

Dr. Assem Safieddine is an Associate Professor and Chairperson of the Finance, Accounting and Managerial Economics Track, Director of the Corporate Governance Program at American University of Beirut, and a board member of the Dubai Ethics Resource Center. He is the founding president of the Lebanese Chartered Financial Analyst Society, regional director of the Global Association of Risk Professionals, and president of the Lebanese Risk Management Society. Dr. Safieddine holds a $\mathrm{PhD}$ in Finance from Boston College. His research has been published in leading finance journals like the Journal of Finance, Journal of Financial Economics, and the Journal of Financial and Quantitative Analysis, and his work has been profiled in the Business Week, Harvard Business Review, CFA Digest, and the National Bureau of Economic Research along with others.

Myriam Rabbath is a recent graduate of the MBA program at the American University of Beirut. She holds an MBA in Finance from the American University of Beirut (Lebanon), and a BA in Business Administration from Haigazian University (Lebanon). Currently, she is working as an analyst in the Organization, Strategy and Planning Department in one of the top five leading banks in Lebanon. 